\title{
Processes of adaptation to climate variability: a case study from the US Southwest
}

\author{
Timothy J. Finan*, Colin Thor West, Diane Austin, Thomas McGuire \\ Emil Haury Anthropology Bldg, Rm 221A, The University of Arizona, PO Box 210030, Tucson, Arizona 85721-0030, USA
}

\begin{abstract}
The nature of adaptation to climate variability in the Southwest US is explored using the Middle San Pedro River Valley in southern Arizona as a case study. An integrated vulnerability assessment focuses on the dynamic interaction of natural climatic and hydrological systems with socio-economic systems. This approach reveals that residents in the study region do not perceive short-term or long-term vulnerability to climate variability or climate change. The paper uses an ethnographic field approach to examine the technical and organizational factors that constitute the adaptation process and reduce vulnerability to climate in the valley. It concludes by discussing the potential dangers of ignoring climate in a rapidly growing, semi-arid environment.
\end{abstract}

KEY WORDS: Climate variability $\cdot$ Climate vulnerability $\cdot$ US Southwest $\cdot$ Livelihood $\cdot$ Adaptation

\section{INTRODUCTION: VULNERABILITY AND ADAPTATION}

It is not surprising that the study of climate vulnerability has drawn much of its empirical evidence from research in the world's severely impoverished regions, where the impacts of climate extremes are often both immediate and dramatic (Davies 1996, Ribot et al. 1996, Liverman 1999). When, for example, drought strikes the semi-arid Northeast of Brazil, no one totally escapes the ensuing effects. Rainfed agricultural production is decimated; livestock herds suffer extreme weight loss or death and often must be moved or sold; drinking water becomes scarce and must be purchased or delivered; staple food prices increase; cities teem with rural refugees; and government officials scurry to save both lives and reputations (Finan \& Nelson 2001). In contrast, in the US Southwest, a multi-year drought may linger unperceived by the majority of the population. Increased fire hazard may limit recreational alternatives; stubbornly high temperatures may sap some energy and increase cooling bills; but, overall, most

*E-mail: finan@u.arizona.edu households in the Southwest have the luxury that Brazilians, Mexicans, and Africans for the most part do not enjoy: they can ignore drought.

Such sweet ignorance, however, has not always been the case. The following historical account from a resident of southeastern Arizona demonstrates that climate vulnerabilities and local perceptions can indeed change:

'The seasons were fitful and spasmodic, drought followed drought then fierce electrical storms ravished the area causing tremendous amounts of water to gush down from the mountains and higher country cutting the valley into deep arroyos and in places depositing huge stretches of rocks, sand, gravel and debris causing great damage to the canal, as well as land in general.' - Grace Fenn, Pomerene resident, 1945 (Bailey 1990, p. 13)

That members of this same community scarcely mention droughts and floods 50 yr later suggests a dynamic adaptive process and an effective reduction in vulnerability that comprise the core theme of this paper.

The literature on drought and drought response in Africa and elsewhere (e.g. Watts 1983, Downing 1991, Corbett 1988, Golnaraghi \& Kaul 1995) vividly demon- 
strates that vulnerability is as much about households and society as about climate variability. Whereas climatic events provide the context for understanding vulnerability, the concept itself is essentially a socioeconomic or ecological one. Bohle et al. (1994, p. 39) identify 3 principal components of vulnerability that most authors agree with-notably, exposure, capacity, and potential. Exposure assesses the direct impacts of a climatic event on a given community ${ }^{1}$, such as loss of crops, water scarcity, and so forth. Capacity in this theoretical framework assesses the ability of the community to respond to a climatic event over the short run; while potential measures the longer-term recovery rate of a given community from a climatic crisis. Thus, the vulnerability of a community (or household) is directly related to its degree of exposure, i.e. the severity of felt climate impacts, and inversely related to the capacity to cope and recover.

Blaikie et al. (1994, p. 9) offer a similar definition of vulnerability as the characteristics of a person or group in terms of the capacity to anticipate, cope with, resist, and recover from the impact of a natural hazard.' It is possible from a social science perspective to think of these 'characteristics of a person or group' as livelihoods (Davies 1996) or complexes of asset endowments and socio-economic strategies meant to promote or protect household well-being. Livelihood systems tend to vary in terms of their respective vulnerability profiles, precisely due to differences in exposure, coping capacity, and recovery potential, thus lending themselves well to the analysis of climate vulnerability in specific spatial and temporal contexts.

With vulnerability, adaptation has acquired a priority focus in climate change research as evidenced in the reports of the Intergovernmental Panel on Climate Change (IPCC) (Watson et al. 1997, McCarthy et al. 2001). If climate vulnerability is an undesirable state of risk faced by an individual or group, adaptation can be seen as the sets of system changes, or behavioral responses, that seek to diminish this vulnerability. Smithers \& Smit (1997) present an account of the theoretical emergence of adaptation across disciplines and propose an approach the specific characteristics of adaptive response in terms of such variables as intent, scale, duration, purpose, and source. These distinctions allow us to think of descriptive forms of adaptation that are often presented in the literature as dichotomous responses, i.e. individual or group, intended or incidental, tactical (short-term) or strategic (long-run),

${ }^{1}$ Community here is used as a convenient unit of vulnerability analysis; other scales of analysis, such as individuals, households, sectors, regions, economies, etc., are clearly relevant to this discussion autonomous (reactive) or planned (proactive), and spontaneous or deliberate (Risbey et al. 1999, Reilly \& Schimmelpfennig 2000, Smit et al. 2000).

We present here what has been called an 'empirical adaptation study' (Smit et al. 2000, p. 243) that applies a vulnerability/adaptation framework to a valley in southeastern Arizona that has experienced significant socio-economic change and continues to do so. Smit et al. (2000) recommend an 'anatomy' of adaptation that dissects any adaptive process into its component units of analysis: who or what adapts, to what are they adapting, and how does adaptation occur. This paper endorses this approach but places a major research focus on the last of these components - the process of adaptation and how it can be documented historically and ethnographically among different livelihood systems with differing levels of vulnerability.

This case study demonstrates how climate variability and an array of socio-economic system characteristics are interwoven to produce patterns of vulnerability and adaptive responses in a desert river valley. Previous studies (e.g. Blaikie et al. 1994, Bohle et al. 1994) have established that political, economic, and social conditions as much as physical and geographic phenomena place certain populations at risk. In southeastern Arizona over the last century, the interplay of environmental and socio-economic processes has created 3 distinct sources of vulnerability to which adaptive responses emerged. At one level, the nature of a semiarid climate, with a highly dispersed spatial and temporal distribution of rainfall, violent rainfall episodes, and extreme summer and winter temperatures, engenders an 'expected' level of climatic variability to which livelihood systems are constantly adapting. Second, in this same region extreme droughts and floods have historically occurred that also stimulated significant adaptive response-some short-run and others more permanent. A third source of vulnerability is embedded in the dynamic interaction between a wider socioeconomic context and patterns of climate variability. For example, changes in prices and policies, the emergence of economic competition in some other region, and other extraneous factors have occurred to increase the significance of climate impacts upon certain livelihoods. If, under one socio-economic scenario, current adaptations permit some degree of freedom with regard to climate variability (e.g. ranchers revert to the use of purchased cattle feed during a short drought period, in the context of favorable cattle prices), a change in the socio-economic conditions (i.e. lower cattle prices) can reduce that flexibility and increase the level of climate vulnerability within the livelihood system.

The question of why a given livelihood system or, at a finer scale, a given household is more or less vulner- 
able has received considerable attention among scholars, especially those that work in the developing world (Blaikie et al. 1994, Adger \& Kelly 1999, Kelly \& Adger 2000). Subjected to careful analysis, this research demonstrates that levels of vulnerability reflect in part the 'success' of a prior or on-going adaptive process and in part the need for future adaptive responses to possible conditions of climatic or socio-economic stress. In effect, vulnerability is ultimately defined by the asset bundles and allocation options that characterize a livelihood or a household-these assets being both material (savings and credit, livestock, concrete buildings, etc.) and non-material (social capital, access to information, eligibility for public programs, etc.). Blaikie et al. (1994) have presented a model in which access to resources-economic, social, and politicaldrives the adaptation process. In their examples, 2 households-one rich and one poor in terms of access - will have very different coping and recovery mechanisms on hand, thus their levels of vulnerability contrast starkly. In a similar vein, Adger \& Kelly (1999), influenced by the seminal contributions of Amartya Sen, have introduced an 'architecture of entitlements' model in which households and social groups adapt by drawing upon a basket of resources, rights, and eligibilities that provides access to financial or material assistance in times of crisis. In this case, what separates the industrial countries from the developing world (or southeast Arizona from Northeast Brazil) is a fuller and more diversified set of entitlements that better equips the former group of countries to adapt to climate variability and future climate change.

As we examine the historical process of adaptation in southeastern Arizona, the focus of inquiry falls upon the manner in which entitlements are procured and mobilized to confront the 3 sources of vulnerability described above. We argue that the sets of adaptive response to the vulnerability of valley livelihoods have worked to buffer these populations from the effects of climate, more of less removing climate extremes from public consciousness and public discourse. We seek to demonstrate that some individual livelihoods have enjoyed a reduction in their levels of vulnerability, while other more buffered livelihood strategies have emerged.

If, in short, the adaptive process has insulated livelihoods and households from the effects of climate extremes, we seek to understand how this has occurred. This case study reveals that 2 basic and interrelated factors create the result observed in the valley. On the one hand, the systematic adoption of new technologies has reduced the impacts of climate variability. Technical change partially explains adaptation in the region and reflects a reliance on human and financial capital (knowledge and money) to reduce vulnerability. The second critical dimension of the adaptive process is found in the changes and readjustments in social organization, or what might be called investments in social and political capital. Not only have new technologies appeared throughout the history of the valley, but new forms of group decisionmaking have also emerged to produce the adaptive impacts we have observed. As Warrick (1983) points out, farmers can shift the individual impacts of a climate event to higher orders of social relations such as insurance companies or taxpayers. In some cases, access to technology is predicated on the development of specific 'enabling' institutions, as in the creation of irrigation districts. In other cases, however, the institutional growth itself, e.g. greater access to outside labor markets, can provide the adaptive response. Conceptually, then, adaptation success is a function of increasingly complex socio-economic configurations - first at a local level involving cooperation among individuals and between households, but later involving the participation of public policy makers.

Thus, this paper explores the manner in which technology and society, including the public sector, have adjusted themselves to reduce the effects of climate to a state of near insignificance in the Middle San Pedro River Valley (MSPRV). While it is possible that a community - comprised of various livelihoods - can effectively buffer the impacts of climate, caution is urged in assuming adaptive success. Kates (2000) questions whether adaptation can be tautologically defined as successful since the long-term effects of adaptation strategies may not yet be known. In southeastern Arizona, where access to water eventually sets the physical limits on human activity, current adaptations may in fact become dysfunctional and destructive in the future. There is no assurance that adaptation generates a positive adaptive response in a systemic or evolutionary sense. On the contrary, Brooks \& Emel's (1995) excellent study of the Llano Estacado demonstrates that some adaptation strategies (such as deep aquifer irrigation) have endangered the long-term viability of livelihoods, in part because farmers have failed to perceive their underlying vulnerabilities. In examining the nature of adaptation in the MSPRV, we are also forced to consider local perceptions of climate variability and vulnerability. Adaptation strategies create routines for dealing with climate variability that reduce its importance in the public perception, sometimes to the point of complacency. It is theoretically possible that the adaptation process will encourage communities to make decisions that over time result in different perhaps more intractable vulnerabilities as decreasing water tables throughout the West exemplify. 


\section{METHODOLOGY: AN ETHNOGRAPHIC INTEGRATED ASSESSMENT}

Easterling (1997) wryly notes that there may be as many integrated assessment models (IAMs) as there are modelers. Readers may be relieved to discover that no new IAM approach is advanced in this paper. To answer the central research question, we compiled all available information on climate and paleoclimate, valley hydrology, and socio-economic characteristics of populations in the study area. In the absence of a data set that could be quantitatively modeled, we generated a qualitative assessment of climate vulnerability by livelihood category (see Finan \& West 1999). In addition, our assessment sought to establish the direction of demographic and economic growth within the middle reaches of the valley, then to relate this trend to the natural limits imposed by climate and hydrology.

In the first phase of research, our methodological approach employed a 'rapid ethnographic assessment' to gather the primary data set (see Finan 1996, for an application of the method, see McGuire \& Austin 1999). The purpose of rapid ethnographic assessment is to elicit qualitative information in an efficient and cost-effective manner, based on key informant and focus group interviews. We deployed a research team (5 to 8 graduate students and senior faculty) in a series of 'concentrated site visits' to the MSPRV. Working initially through 'gatekeepers', key officials in the communities, we employed a 'snowball sampling' technique. The gatekeepers identified potential informants in the communities, representing diverse economic and public service sectors. These individuals, once interviewed, in turn provided names of other informants. The interviews themselves followed a semistructured format, in which the researcher is equipped with a template or guideline for questioning, specific to the sector represented by the informant. The guideline is not as constraining as a formal questionnaire, since it allows both informant and interviewer to explore new leads and interpretations as they arise through the discussions. Individual interviews frequently lasted for an hour or more. In addition to oneon-one interviews, we utilized focus group discussions. Led by a moderator from our research team, a group of individuals (for example, members of a local water users' association) would be asked to discuss issues common to that group, such as how rate structures related to droughts.

The rapid ethnographic assessment differs from the conventional 'rapid rural appraisal' (RRA) methodology (Beebe 1995) in that the breadth and depth of the research coverage are greater and more systematic. Contrary to a normal RRA, the ethnographic assessment employs a larger team and carries out repeat visits to the same research sites, or even same informants. Finally, this technique is highly participatory, and the community is presented with the report and given an opportunity to respond to the analysis and the findings. Subsequent community comments are duly incorporated into the final version.

A form of data triangulation was used in the sense that multiple individuals are interviewed about specific events, economic and environmental changes, and, in the case at hand, perceptions of climate variability and livelihood vulnerability. The responses are compared; if inconsistencies are apparent, additional individuals are interviewed until common patterns emerge. This iterative process was facilitated during our concentrated site visits by frequent meetings of the research team, in which notes were shared, narratives were compared, and new interview assignments made. More than 60 representatives of the region were contacted and interviewed, some of them several times. The sample included farmers, ranchers, industry executives, utilities managers, local business owners, visitors, real estate agents, educators, RV park owners, and social services providers. These data provided the background and context for assessing vulnerability and adaptation strategies.

A second phase of the research, based on the preliminary findings, utilized approximately 15 oral histories from local ranchers, farmers, business owners, and historians, to identify the factors that had contributed to the reduction of climate vulnerability and to document the process of adaptation. These participants were selected because their families had resided in the MSPRV for several generations and they had knowledge of each sector. The research team also compiled precipitation data from the last $100 \mathrm{yr}$ and identified key historical events during the same period. This 'graphic organizer' helped elicit information from informants concerning specific periods of drought and flooding (Fig. 2 is a modified example of the organizer). These oral histories shed particular light on the social and organizational aspects of adaptation and identified events and social networks that were most crucial and effective.

The rapid ethnographic assessment is an intense field tool that requires a high level of team coordination. Its advantage is to provide a representative assessment of climate-society interactions, with a focus on climate perceptions. This approach examines linkages both within the community and with people, places, and institutions beyond its borders. Indeed, one strength of a community ethnographic assessment is the ability to explore the various factors and how they are interrelated, investigating critical connections that may go unnoticed in a statistical analysis of relationships among variables. 


\section{THE MIDDLE SAN PEDRO RIVER VALLEY}

The MSPRV was selected as the study site for several reasons. First, it generally represents the kinds of demographic and economic changes occurring over much of the Southwestern US; second, its climate is highly variable and is subject to drought (or flooding); third, surface and groundwater availability represents one of the primary constraints to human livelihood sustainability, thus underlining the critical linkages between climate variability, hydrology, and society (Liverman et al. 1998, Morehouse et al. 1998).

In hydrologic terms, the MSPRV sits within the Upper San Pedro Basin, which extends from its headwaters in Mexico to a point called the Narrows, 12 miles (approx. $19 \mathrm{~km}$ ) north of Pomerene, Arizona (Maddock 1998). The main population concentration is found in the community of Benson, with a permanent population of about 4500 . The rural community of St. David (6 miles south of Benson) has a population of about 2000, and Pomerene (several miles north of Benson) is a smaller community of households surrounding a Mormon church and a post office (see Fig. 1). Northwest of Interstate 10, a major cross-country trunkline, is located a recent concentration of homesites, many of which constitute a 'bedroom community' for Tucson, about 35 miles $(56 \mathrm{~km})$ away. About 5 miles $(8 \mathrm{~km})$ from downtown Benson, commercial development is

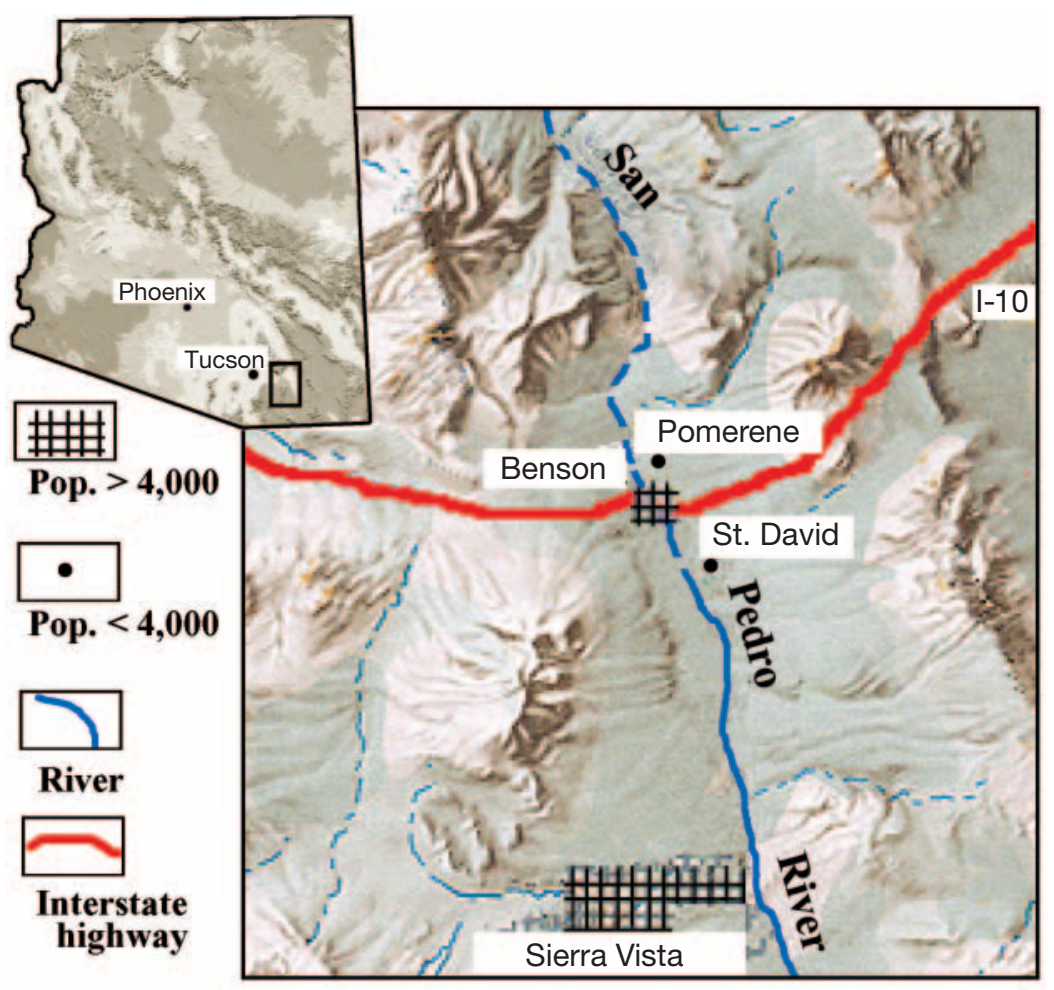

Fig. 1. Arizona and the Middle San Pedro River Valley occurring very rapidly in the wake of the opening of Kartchner Caverns State Park, the underground marvel that is expected to attract 150000 visitors annually. Benson has annexed the area around the Caverns and identifies itself as the (copyrighted) 'Home of the Kartchner Caverns.' About 25 miles $(40 \mathrm{~km})$ south and upstream of Benson is the rapidly growing city of Sierra Vista (about 40000 inhabitants), with its increasing demand on groundwater supplies. The San Pedro Riparian National Conservation Area (SPRNCA) lies between Sierra Vista and Benson and is protected from land use change.

The history of the MSPRV is a chronology of settlements attracted by good soil and abundant water. While indigenous peoples have been in the region for $12000 \mathrm{yr}$, written records document the arrival of Spaniards 450 yr ago (Sheridan 1996). Anglo settlers supplanted Apache tribes during the second half of the 19th century, as they came to farm, ranch, hunt, and mine. In the 1880s the Southern Pacific Railroad linking El Paso and Tucson (through Benson) was finished, and the concentration of switching operations in Benson brought a major source of employment to the region.

Prior to the arrival of the Spanish, Pima-speaking indigenous tribes had practiced irrigated agriculture along the San Pedro until warfare with the Apaches forced them to abandon their settlements. The Spanish, never very numerous in the region, introduced cattle. During the middle of the 19th century, Mormon troops on their way to fight in the Mexican-American War passed through the San Pedro River Valley and noted its abundant land and water resources. After the Gadsen Purchase in 1853, Mormon families arrived and helped supplant the indigenous tribes, mostly Apache groups, that hunted and gathered along the river. The Mormons brought farming and ranching to the area, establishing the communities of Pomerene and St. David.

The town of Benson was founded in 1880 as a stop on the Southern Pacific Railroad at the site chosen for a bridge over the San Pedro River. It quickly became the 'Hub City' - a center of railroad and stage lines east and west, as well as the northern terminus of the railroad from the mining and coastal areas of Sonora, Mexico. Benson served as a center for north-south as well as east-west transportation during the late 19th century, especially for 
ore shipment as the mining industry developed rapidly in southern Arizona and northern Mexico in the early 20th century. In 1913, however, the railroad moved its operations to Tucson, and the economic base switched back to farming and ranching. These 2 activities remain significant livelihoods in the valley in terms of land use, if not economic importance.

Over the last $50 \mathrm{yr}$, perceptible changes in these socioeconomic patterns have occurred. The routing of the interstate highway through Benson, the growth of Tucson, the emergence of Sun Belt demographic shifts, and now the Caverns have all combined to alter the economic emphasis from ranching and farming toward recreation, tourism, and retirement. Increasingly, the MSPRV has attracted those who flee the urbanization (and perceived crime) of Tucson, the elderly retired seeking affordable living in their golden years and modern day nomads who seasonally eschew the cold of Midwestern winters. In sum, the valley presents a composite of livelihoods that intertwines historical adaptations with current economic transformations.

\section{CLIMATE AND HYDROLOGY IN THE MSPRV}

The climate of the MSPRV is semi-arid and warm, averaging around 13 in $(33 \mathrm{~cm})$ of rainfall annually. Climate variability expresses itself seasonally in that the distribution of precipitation is bimodal-a monsoon summer season based on the arrival of tropical moisture originating in the Gulf of Mexico, the Gulf of California, and the eastern tropical Pacific Ocean (Adams \& Comrie 1997, Sheppard et al. 1999) and the winter rainy season that brings frontal systems from the northern regions of the Pacific Ocean. Climate variability is characterized by anomalies to this pattern-below-average precipitation (drought), abnormal excess of rainfall (flooding), late or early onset of the seasons, and temperature extremes. On the one hand, the impacts of such climate variability (in vulnerability terms, the level of exposure) are manifest in the quantity of surface water in the valley, the magnitude of groundwater recharge, and changes in flora and fauna patterns. On the socioeconomic side, such climate variability can incur short-term impacts on the provisioning of electricity (for heating, cooling, irrigation, and lighting), the costs of ranching and farming, the incidence of certain disease vectors (valley fever), floodwater destruction, and reductions in tourism and business. Over a longer term, climate variability may affect the availability of ground and surface water supplies, although further research is needed to establish the nature of this constraint.
Common wisdom in the Southwest asserts that 'water is gold,' and future growth is ultimately linked to the availability of this critical resource. The communities in the MSPRV exemplify this reality, for they depend on surface flow and groundwater for both irrigation and human consumption. The San Pedro River runs permanently in stretches upstream (south) of St. David, but only intermittently through the middle valley. In the past, the river would flow beginning in November and continue on through the winter. Under the low rainfall conditions of the last $5 \mathrm{yr}$, the riverbed has been dry except for ephemeral runoff immediately following a storm. In Pomerene and St. David, both agricultural communities, surface water has traditionally been diverted to ditch systems for irrigation.

The highly variable supply of surface water increases the overall dependence on groundwater. The MSPRV has a wide valley floor with 2 main sediment layers and an underlying area of consolidated rock that joins the surrounding mountains. The 2 sediment layers are the primary sources of groundwater and make up the regional and the floodplain aquifers (Chronic 1998, p. 53). The regional aquifer is the largest source of groundwater with an estimated $33.6 \mathrm{~km}^{3}$ (27.2 million acre-ft) of recoverable groundwater stored in the Benson subwatershed (Arizona Department of Water Resources 1991). This water is available at depths

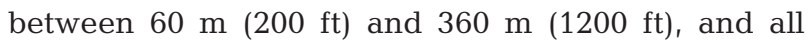
the community water systems maintain wells in this aquifer as the primary source of municipal water. The floodplain aquifer is located in the younger alluvium that overlays the older alluvium along the stream course. While average floodplain well yields are generally higher than in the regional aquifer (up to 10000 $1 \mathrm{~min}^{-1}$ or 2700 gallons $\mathrm{min}^{-1}$ ), the overall amount of recoverable groundwater stored in the flood plain alluvium in the Benson watershed is limited to approximately $0.153 \mathrm{~km}^{3}$ or $153 \times 10^{6} \mathrm{~m}$ (124000 acre-ft; ADWR 1991). Well depths are usually between $12 \mathrm{~m}$ $(40 \mathrm{ft})$ and $46 \mathrm{~m}(150 \mathrm{ft})$.

Table 1 summarizes the water balance for 1990, comparing the Benson subwatershed with the one upstream at Sierra Vista. These data demonstrate that agriculture is still a major user of water in the MSPRV, despite its overall economic decline. When surface water is not available due to climate variability, most farmers switch to wells and irrigate with groundwater. In these years, the demand on groundwater supplies exceeds the recharge capacity of the watershed, thus reducing the overall aquifer supply. These data also demonstrate the upstream imbalance between recharge and water use. The impacts of overdraft in Sierra Vista on downstream communities are not well known, but already a matter of public concern. 
Table 1. Water supply and demand in the Benson and Sierra Vista subwatersheds. Source: Arizona Department of Water Resources (1991)

\begin{tabular}{|lcc|}
\hline Water supply & $\begin{array}{c}\text { MSPRV sub- } \\
\text { watershed 1990 } \\
\left(10^{6} \mathrm{~m}^{3} \mathrm{yr}^{-1}\right)\end{array}$ & $\begin{array}{c}\text { Sierra Vista sub- } \\
\text { watershed 1990 } \\
\left(10^{6} \mathrm{~m}^{3} \mathrm{yr}^{-1}\right)\end{array}$ \\
\hline Surface water inflow + tributaries & 62.9 & 50.2 \\
Surface water outflow & 31.4 & 48.3 \\
Total surface water (inflow - outflow) & $31.4(56 \%)$ & $1.9(6 \%)$ \\
Natural groundwater recharge & 14.5 & 20.8 \\
Incidental groundwater recharge & 9.5 & 3.2 \\
Total groundwater & $23.9(43 \%)$ & $24.0(79 \%)$ \\
Effluent & 0.7 & 4.4 \\
Total renewable supply & $56.0(100 \%)$ & $30.3(100 \%)$ \\
Total water demand & 53.6 & 45.6 \\
Municipal & $1.8(3 \%)$ & $13.6(30 \%)$ \\
Agriculture & $26.6(50 \%)$ & $7.6(17 \%)$ \\
Industrial & $0.7(1 \%)$ & $0.3(1 \%)$ \\
Riparian vegetation & $21.8(41 \%)$ & $17.8(39 \%)$ \\
Other & $2.8(5 \%)$ & $6.3(14 \%)$ \\
\hline
\end{tabular}

ease of access to Tucson, 35 miles $(56 \mathrm{~km})$ away. These families commute daily to their jobs in the city, but prefer the crimefree, open environment that the valley offers them. With the opening of Kartchner Cavern State Park, this urbanization trend is expected to intensify and has already begun to concentrate the economic base in the business and services sectors.

For the purposes of a vulnerability assessment, it is possible to examine 2 major livelihood categories. The first, which displays the greatest level of vulnerability to climate variability, is ranching and farming. We have chosen to combine these distinct activities, because they are interdependent and both have seen their relative importance decline over the

\section{LIVELIHOOD VULNERABILITIES AND ADAPTATION}

Livelihoods in the valley have changed through time and are undergoing further transformation as part of the national demographic shift to the Sun Belt (Finan \& West 1999). In the 1920s, the first industrial operation was established in the MSPRV, when mining interests seeking a cheaper source of dynamite founded the Apache Powder Company in St. David. Later, the company was changed to Apache Nitrogen, and the manufacturing focus expanded to a range of nitrogen products for both mining and agriculture. Another manufacturing firm, which produces metal castings for other industrial uses, moved to Benson in 1994. The impact of this industrial sector and the approximately 100 jobs that it generated in the valley has been to provide families, particularly those of farmers and ranchers, an opportunity to diversify their livelihoods.

The current economic transformation in the MSPRV began with the construction of the east-west interstate, I-10, through Benson, but is part of a wider demographic re-structuring in the United States as a whole. In recent years, Benson and the rest of the MSPRV have experienced a significant increase in overall population, especially among those over $65 \mathrm{yr}$ of age (Arizona Department of Economic Security 1998: www.de.state.az.us/). The somewhat cooler climate of the valley relative to Tucson coupled with the proximity to a major urban center with comprehensive health services has attracted both retirees and seasonal tourists. In this latter category are the 'recreational vehicle' devotees (RVers), a well-organized and highly mobile group of road tourists that have shown a preference for the Benson region. Still-working families have also been attracted to the valley because of the last few decades. The second livelihood is that of urban commercial and services, which again combines many different forms of economic activity that face similar vulnerability realities. In each case, we describe the nature of the vulnerability and the forms of adaptation that have been employed to buffer climate variability and extreme events.

\subsection{Ranching and farming: system characteristics}

Although first introduced by the Spanish, cattle in large numbers followed the railroad into the MSPRV. As in the rest of the Southwest, most available rangeland is in public hands (58\% in Cochise County) and is managed either by the state or by federal agencies such as the Bureau of Land Management or the Forest Service. Any given ranch is usually comprised of a large amount of leased public land, supplemented by a small amount of deeded private property. Leases are negotiated as a function of the carrying capacity of the land (expressed in 'cow-units'), but a large holding of leased land does not imply large herds, since range quality is also considered. Conley et al. (1999) report that for Cochise County as a whole, only $20 \%$ of the ranching operations have more than 200 head of cattle, the herd size used to define a commercial ranch. The typical ranch in the MSPRV is a cow-calf operation that produces annual calves for the feeder market. The success of a ranch is largely dependent, although not exclusively so, upon the annual quality of the range, itself a function of the quantity and distribution of rainfall. When summer or winter rains fail to provide the necessary moisture for pasture development, ranchers are forced to move their herds, sell them, or purchase supplemental feed, all of which increase significantly 
the economic vulnerability of the operation. Ranchers especially fear extended drought because of the more long-lasting impacts that can degrade the range (by favoring less palatable but more drought-resistant species), dry up water ponds and wells, and depress market prices.

Bahre (1991) reported that, during the drought of 1891-93, up to $70 \%$ of the cattle herd in Cochise County perished on the range. Even today in the neighboring states of northern Mexico, recent droughts have devastated local cattle herds and severely affected the rural economy (Liverman 1999, p. 113). In contrast, most MSPRV ranchers have been able to cope with the impacts of recent droughts in such a way that permits rapid recovery of the production system. From the perspective of management practice and technology, ranchers distribute their pastures over diverse parts of the range, set stocking rates that maintain vegetative cover, use rotational grazing, and scatter wells and ponds so as to mitigate the impacts of highly variable temporal and spatial climate regimes. In the case of extreme drought, the adaptive mechanisms are mobilized within a wider socio-economic context. One old-timer, a descendent of a pre-Gadsen Hispanic family, rented farmland in a neighboring valley during the great drought of the 1950s, grew feed, and shipped his cattle there, an adaptive response dependent upon personal contacts, infrastructural development, and transportation availability (as well as a land rental market). At the time of our interview, his outbuildings were stocked with purchased hay in anticipation of the 2000 La Niña drought. He had also installed windpowered wells in 2 critical parts of the rangeland where animals could be herded if earthen ponds dried up. Some ranchers sell their entire herd during a crisis, then reacquire heifers when the rains return. Others retain only the reproductive herd (cows) on supplemental feed purchased from irrigated farms in the valley.

Federal programs such as the Range Conservation Program and the Natural Resource Conservation Services (NRCS - formerly the Soil Conservation Service) made it possible for individuals to install wells, windmills, and pipes on the range. To cope with the spatial variability of rainfall, one descendant of homestead ranchers described the common practice whereby operators would strategically space their cattle tank and wells within 2 miles $(3.2 \mathrm{~km})$ of streams or springs so that herds never have to roam more than a day between water sources. This strategy is facilitated by the public programs that shared costs. The NRCS also promotes watershed management projects through Natural Resource Conservation Districts (NRCDs) composed of local ranchers and farmers who own operations within the same watershed. As members of the
Benson NRCD, these ranchers obtain low-interest loans for improvements, which are approved by and evaluated by the district board. The Benson NRCD provides a clear example of how the introduction of adaptive technologies is intertwined with the reorganization of stakeholders into larger social entities.

Adaptive responses have been built primarily on the integration of ranch households into a wider society and the regional economy. While any drought is painful, the ability to access feed markets, rent farmland, and even to obtain public disaster assistance provides the necessary buffers against the most devastating of consequences. Our interviews also document that most, if not all, ranch households have traditionally diversified their income sources with outside employment revenue, a strategy that also helps to mitigate climate-based crises. It is well known that in recent decades the economic incentives to ranching have diminished dramatically, and large ranches have been sold and broken into small-acreage 'ranchettes' (Conley et al. 1999, Finan \& West 1999) attractive to those who desire a Western experience without the economic struggle of running cattle. While the amount of ranchland converted to other uses has expanded over the last 2 decades, the changing social and economic environment, rather than vulnerability to climate variability, has provided the principal thrust to this trend.

Historically, farming in the MSPRV was highly vulnerable to climate variability. Dry land agriculture was practiced in the valley at the turn of the century, and one individual proudly pointed out fields of maize and beans that he had farmed up until the 1940s. Early farmers faced the 2-pronged threat of drought, which eliminated dry farming and reduced access to surface water for irrigation, and increased flooding in years of excess precipitation. In the latter case, flood dangers were exacerbated by the over-stocking of pastures on feeder watersheds upstream, since the consequent reduction in vegetation cover increased run-off and erosion. For example, in 1931 floods destroyed the entire irrigation systems of both Pomerene and St. David (see Fig. 2). Extreme temperatures also posed a climate threat, since the cooler San Pedro watershed can experience frosts in mid-spring. Currently, there are 800 acres (324 ha) under cultivation in the MSPRV, out of 6000 (2430) potentially farmable acres (ha) (Cochise County Cooperative Extension 1997, p. 6). Cotton, once an important cash crop, has been replaced mostly by alfalfa, tree crops such as pecans, and truck farming. One large dairy operation is perhaps the only one that can be characterized today as a fully commercial enterprise.

The history of farming in the MSPRV readily demonstrates the cumulative process of adaptation to climate 
vulnerability. Early members of the Church of Jesus Christ of Latter Day Saints (Mormons) realized that climate variability made dry farming precarious and reduced the availability of surface water. Thus, the first adaptive response was to build dams that could store water for diversion into a ditch system. In 1908, residents of Pomerene formed the Benson Canal Company (BCC) in order to obtain financing for a professionally engineered irrigation system. The money came from a lending institution in Denver and water was allocated based on shares that members purchased. Although not all of these initial shareholders were Mormon, the local Mormon Church of Latter Day Saints organized labor for the BCC's initial construction. The Church's ability to mobilize labor and provide matching funds was also crucial in the reconstruction of the Pomerene and St. David canals by the Civil Works Administration in 1933 (Bailey 1990, p. 33).

A local historian whose family has resided in Pomerene since 1912 recounted her memories of the Pomerene Canal. She called it 'their lifeline' and described how farmers 'guarded every drop of water from it tenaciously.' If a headgate broke or leaked, the ditch boss would immediately fix it. She remembered that the canal was also a source of disputes and friction over the timing and quantity of headgate releases. Another long-time farmer in St. David told us that if there were not enough rain to provide river water for the canal, then residents simply would not plant. Thus, in times of extended drought, the BCC and St. David ditches were not able to sustain all the users; hence climate variability constituted an important constraint.

Farmers began installing wells into the alluvial aquifer in 1940 that, coupled with the arrival of electricity to the valley, gave greater flexibility to individual households and virtually eliminated the impacts of climate extremes. While touring the St. David ditch, a local informant noticed that irrigation water from one farm was overflowing across the road. Our guide expressed little concern and this behavior conflicted with earlier testimonies whereby all water was carefully guarded and managed. The availability of irrigation wells has thus altered current perceptions of water scarcity as well as having reduced vulnerability. No one in our sample can remember wells ever going dry. One Mormon farmer related in an interview that the other major adaptive factor was the establishment of the Apache Powder Company in St. David, which allowed families to combine farming with outside employment. The income from company employment gave families the capital to invest in more secure irrigation systems for their farms as well as a stable source of 'climate-free' income.

Farming is still an important livelihood in the MSPRV in terms of land and water use, but it has, like ranching, fallen victim to economic change more than to climate variability. The demand for small parcels of rural property, with its concomitant lifestyle, is rapidly increasing, and the economic incentive to subdivide and sell is irresistible to many families, even those that identify closely with farming and ranching. It is important to note, nonetheless, that the perceived absence of climate vulnerability, due to the existence of wells, makes the 20 -acre ( $8 \mathrm{ha}$ ) homesite attractive to residents, thus favoring the transformation already under way.

\subsection{Urban livelihoods}

Where ranching and farming are experiencing a decline in terms of relative importance, urban livelihoods have grown. Urban populations perceive climate vulnerability as a much more distant or indirect phenomenon. With economic growth concentrated in tourism, particularly from seasonal visitors, business operators and RV campsite owners are more concerned with climate variability at the source from whence the tourists come. Early onset of winter in the Midwest generates great interest and speculation among tourism service providers in Benson. Extreme cold or excessive rainfall in the winter might affect local business, but the impacts are mostly ephemeral. For retirement and bedroom community residents, comparison with the climate in Tucson is the measuring stick of relevance, since no matter how hot the MSPRV gets in summer, Tucson will be hotter. For the 2 manufacturing sites in the valley, extreme temperatures are a matter of safety concern for workers exposed to furnaces and heating processes. In general, however, both companies have contingency plans to respond to excessive temperatures in the production environment.

The lack of any direct concern with climate extremes is shared by both energy and water providers. In the case of water, the municipal water managers for Benson, St. David, and Pomerene do not consider the availability of groundwater to be an issue, and in Benson the major priority is to expand the current system to meet increased demand. None of the water providers has an outreach program of consumer water conservation, as the Tucson system does. Similarly, the electric utility considers extreme summer temperatures to be a vulnerable point due to a 'peak' in demand that exceeds system capacity. A tightly monitored system has been implemented to shut off certain transformers when a 'danger point' is reached. In exchange for a subsidized rate structure, farmers in the valley have agreed to curtail irrigation when such actions must be taken by the utility. 
Families in the MSPRV tell of hanging burlap sacks from trees and running water through them to create a cool micro-space to combat the heat, a precursor technology to the ubiquitous evaporative cooler. In fact, it is technology and the social and public institutions needed to distribute technology that have produced the kinds of buffers that make climate vulnerability appear so remote. Evaporative coolers and air conditioners control the ambient environment at a small cost; virtually all residences have running water; dengue fever has not arrived, and people do not see valley fever as climate-related. Since most business activity has now become independent of local climate variation, the residents of the MSPRV perceive drought, excessive rain, or extreme temperatures as tolerable annoyances rather than threats to livelihood.

\section{VULNERABILITY AND ADAPTATION IN THE SOUTHWEST}

Fig. 2 spans 100 yr of climate variability in the MSPRV and associates extreme climate events with both impacts and certain technological or institutional initiatives that appear as specific 'adaptation points.' In part, this historical sequence reveals the role of tech- nology, of local socio-economic organization, and of public decision-making in climate mitigation. Dams are built, water associations are organized, wells are opened, electricity is brought in, industry arrives with less climate-vulnerable employment alternatives, and public disaster assistance is introduced-with the result that the public perception of climate vulnerability is minimized.

The systematic adaptation to climate impacts, however, does not necessarily provide permanent solutions, and the dynamic interaction of climate and society may make certain adaptations as obsolete and as impractical as the burlap sacks of $60 \mathrm{yr}$ ago appear today. Undeniably, climate and hydrology establish natural limits that, at the current time, seem remote and non-binding. Our assessment suggests that perhaps climate vulnerability has become poorly perceived precisely because of such successful adaptation. On the other hand, the MSPRV projects clear demographic trends that - together with different kinds of societal demands - will alter the way in which natural resources are used, forcing society to review these natural limits. It is plausible to assume that societal values, thus public priorities, are subject to change. As an example, an intensified public commitment to conserving or restoring the riparian environment might

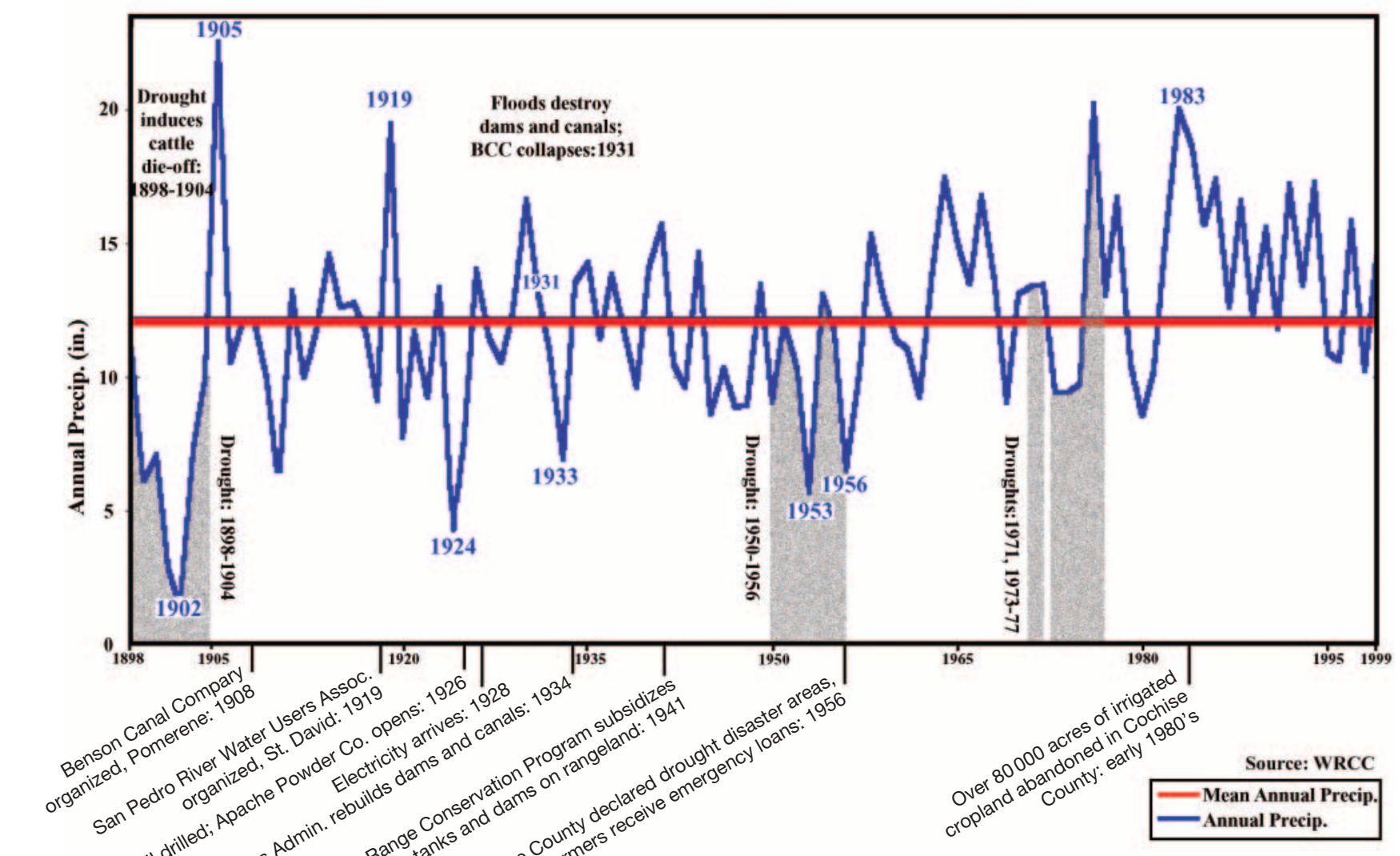

Fig. 2. Precipitation and adaptation events, 1898-1999 
require a shift in water use away from municipal growth and toward wetland maintenance. Downstream river rights claimed by the Gila River Indian Community could restrict upstream usage. The increased contestation over access to water among different economic interests and value systems could well result in a greater perceived vulnerability to climate than the one that currently prevails.

\section{CONCLUSIONS}

A quantitative assessment model would attempt to establish the actual population limits and the different livelihood combinations that the MSPRV could sustain under current climate conditions and under different scenarios of climate variability and change.

Here, our goals are more qualitative in that we seek to document current socio-economic trends against a backdrop of climate variability and natural resource limits. The paper looks backward to see how vulnerability to climate has changed and how the adaptation process has unfolded. But it also looks forward to assess how natural and human systems may interact given current transformations.

Current demographic and economic trends in the Southwest United States clearly demonstrate a pattern of changing livelihoods throughout the region. In Arizona, heavy in-migration and an increasing median age have altered the socio-economic complexion of small communities that once owed their existence to cattle, cotton, and copper. This paper focuses on such a community, or string of communities, located along the Middle San Pedro River, where the railroads, ranching and farming attracted the original residents, but where tourism and retirement now constitute the basis of the local economy. Applying an integrated assessment approach based on rapid ethnography, we explored the changing impacts of climate variability on the livelihoods in this valley, demonstrating how the process of adaptation has buffered not only the actual impacts of climate extremes, but also the local perception of climate as a critical feature of household or community decision-making. As we trace the socioeconomic changes in these communities highlighted against hydrologic, climatological, and institutional realities, it is possible to assess the complexities of climate vulnerability and the potential role of improved climate information systems.

From one perspective, the adaptation process demonstrates the creative ingenuity of human populations to overcome the constraints that climatic variability once imposed. On the other hand, the integrated assessment approach forces us to regard the victory as tenuous, given the dynamic interaction of social and natural systems. It is unwise to be lulled into the conviction that climate no longer matters, for history suggests otherwise. Rather, a better understanding of climate and its impact on nature and society is needed to guide the human decisions that determine the course of events.

\section{LITERATURE CITED}

Adams DK, Comrie AC (1997) The North American monsoon. Bull Am Meteorol Soc 28:2197-2213

Adger WN, Kelly PM (1999) Social vulnerability to climate change and the architecture of entitlements. Mitig Adapt Strat Global Change 4(3/4):253-266

ADWR (1991) Hydrographic survey report for the San Pedro River watershed, Vol I: General Assessment regarding the general adjudication of the Gila River system and source. Arizona Department of Water Resources, Phoenix, AZ

Bahre CJ (1991) A legacy of change: historic human impact on vegetation of the Arizona borderlands. University of Arizona Press, Tucson, AZ

Bailey WC (1990) The Benson Canal Company and the settlement of Pomerene, Arizona. Manuscript in Arizona Historical Society, Tucson, AZ

Beebe J (1995) Basic principles and techniques of rapid appraisal. Human Organiz 54(1):42-51

Blaikie P, Cannon T, Davis I, Wisner B (1994) At risk: natural hazards, people's vulnerability, and disaster. Routledge, New York

Bohle HG, Downing TE, Watts MJ (1994) Climate change and social vulnerability: toward a sociology and geography of food insecurity. Global Environ Change 4(1):37-48

Bolin R, Stanford L (1999) Constructing vulnerability in the First World: the Northridge earthquake in Southern California, 1994. In: Oliver-Smith A, Hoffman SM (eds) The angry Earth: disaster in anthropological perspective. Routledge, New York, p 89-112

Brooks E, Emel J (1995) The Llano Estacado of the American Southern High Plains. In: Kasperson JX, Kasperson RE, Turner BL II (eds) Regions at risk: comparisons of threatened environments. United Nations University Press, Tokyo, p 255-303

Bryant CR, Smit B, Brklacich M, Johnston TR, Smithers J, Chiotti Q, Singh B (2000) Adaptation in Canadian agriculture to variability and change. Clim Change 45(1): 181-201

Burton I (1997) Vulnerability and adaptive response in the context of climate and climate change. Clim Change 36(1/2):185-196

Burton I, Kates RW, White GF (1978) The environment as hazard. Oxford University Press, New York

Chronic H (1998) Roadside geology of Arizona. Mountain Press, Missoula, MT

Cochise County Cooperative Extension (1997) Cochise County agriculture. University of Arizona, College of Agriculture, Tucson, AZ

Conley J, Eakin H, Sheridan TE, Hadley D (1999) CLIMAS Ranching Case Study: Year 1. CLIMAS Report CL3-99, University of Arizona, Tucson. Available at www.ispe. arizona.edu/climas/reportseries/ranching.pdf

Corbett JEM (1988) Famine and household coping strategies. World Develop 16(9):1099-1112

Davies S (1996) Adaptable livelihoods: coping with food insecurity in the Malian Sahel. St. Martins Press, New York

Easterling WE (1997) Why regional studies are needed in the 
development of full-scale integrated assessment modeling of global change processes. Glob Environ Change 7(4): 337-356

Finan TJ (1996) Anthropological research methods in a changing world. In: Moran EF (ed) Transforming societies, transforming anthropology. University of Michigan Press, Ann Arbor, MI, p 301-324

Finan TJ, Nelson DR (2001) Making rain, making roads, making do: public and private adaptations to drought in Ceará, Northeast Brazil. Clim Res 19:97-108

Finan TJ, West C (eds) (1999) An assessment of climate vulnerability in the Middle San Pedro River Valley. CLIMAS Report CL3-00. University of Arizona, Tucson, AZ; available at http:/www.ispe.arizona.edu/climas/reportseries/ benson/front.pdf

Golnaraghi M, Kaul R (1995) The science of policymaking responding to ENSO. Environment 37(4):16-44

Kasperson RE, Kasperson JX, Turner BL II, Dow K, Meyer WB (1995) Critical environmental regions: concepts, distinctions, and issues. In: Kasperson JX, Kasperson RE, Turner BL II (eds) Regions at risk: comparisons of threatened environments. United Nations University Press, Tokyo, p 1-41

Kates RW (1985) The interaction of climate and society. In: Kates RW, Ausubel J, Berberian M (eds) Climate impact assessment: studies of the interaction of climate and society, SCOPE 27. John Wiley \& Sons, Chichester, p 3-36

Kates RW (2000) Cautionary tales: adaptation and the global poor. Clim Change 45(1):5-17

Kelly PW, Adger WN (2000) Theory and practice in assessing vulnerability to climate change and facilitating adaptation. Clim Change 47(4):325-352

Liverman D (1999) Vulnerability and adaptation to drought in Mexico. Nat Resour J 39:99-115

Liverman D, Merideth R, Holdsworth A (1998) Climate variability and social vulnerability in U.S.-Mexico border region: an integrated assessment of the water resources of the San Pedro River and Santa Cruz River basins. University of Arizona, Tucson, AZ

Maddock T (1998) Middle San Pedro River Valley: study on stream-flow and water-table conditions and their interactions in riparian areas. Department of Hydrology and Water Resources, University of Arizona, Tucson, AZ

McCarthy JJ, Canziani OC, Leary NA, Dokken DJ, White KS (eds) (2001) Climate change 2001: impacts, adaptation and vulnerability. Contribution of Working Group II to the Third Assessment Report of the Intergovernmental Panel on Climate Change. Cambridge University Press, Cambridge

Submitted: June 14, 2000; Accepted: December 17, 2001
McGuire T, Austin D (1999) Gulf Coast communities: land, water, work and education. Bureau of Applied Research in Anthropology Report, University of Arizona, Tucson, AZ

Morehouse B, Comrie AC, Angersbach K, Eakin H, Carter R, Tschakert P, Gardner A, Benequista N (1998) Climate variability in the Southwest region: a contextualization of climate variability in Arizona and New Mexico. CLIMAS, University of Arizona, Tucson, AZ

Oliver-Smith A, Hoffman SM (1999) The angry earth: disaster in anthropological perspective. Routledge, New York

Reilly J, Schimmelpfennig D (2000) Irreversibility, uncertainty, and learning: portraits of adaptation to long-term climate change. Clim Change 45(1):253-278

Ribot JC, Magalhães AR, Panagides SS (eds) (1996) Climate variability, climate change, and social vulnerability in the semi-arid tropics. Cambridge University Press, Cambridge

Risbey J, Kandlikar M, Dowlatabadi H, Graetz D (1999) Scale, context and decision-making in agricultural adaptation to climate variability and change. Mitig Adapt Strat Global Change 4(2):137-165

Sheppard PR, Comrie AC, Packin GD, Angersbach K, Hughes MK (1999) The climate of the Southwest. CLIMAS Report CL1-99, University of Arizona, Tucson, AZ; available at www.ispe.arizona.edu/climas/reportseries/swclimate/main. pdf

Sheridan TE (1996) Arizona: a history. University of Arizona Press, Tucson, AZ

Smit B, NcNabb D, Smithers J (1996) Agricultural adaptation to climatic variation. Clim Change 33(1):7-29

Smit B, Burton I, Klein RJT, Wandel J (2000) An anatomy of adaptation to climate change and variability. Clim Change 45(2):223-251

Warrick RA (1983) Drought in the US Great Plains: shifting social consequences? In: Hewitt K (ed) Interpretations of calamity from the viewpoint of human ecology. Allen and Unwin, Inc, Boston, MA, p 67-82

Watson RT, Zinyowera MC, Moss RH (eds) (1997) The regional impacts of climate change: an assessment of vulnerability. Cambridge University Press, Cambridge

Watts M (1983) Silent violence: food, famine and peasantry in northern Nigeria. University of California Press, Berkeley

WRCC (1999) Benson and Tombstone, Arizona: monthly total precipitation. Western Regional Climate Center, Reno, NV. Available at www.wrcc.dri.edu/summary/climsmaz. html

Yohe G (2000) Assessing the role of adaptation in evaluating vulnerability to climate change. Clim Change 46(3): $371-390$

Proofs received from author(s): June 17, 2002 